
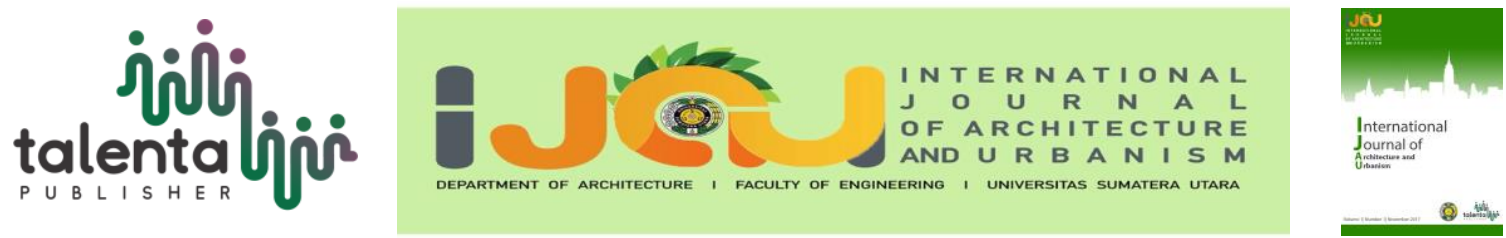

\title{
Reliability Analysis of Fire Stairs in Hospital Buildings (Case Study: Malahayati Islamic Hospital and University of North Sumatra Hospital)
}

\author{
Zielisa Nur Qadimah ${ }^{1 *}$, N. Vinky Rahman ${ }^{1}$ \\ ${ }^{1}$ Architecture Departement, Faculty of Engineering, Universitas Sumatera Utara, Medan, Indonesia
}

\begin{abstract}
One important aspect of hospital buildings is the safety of the occurrence of fire hazards, especially in the fire stairs. The hospital is classified as very crowded because of the large number of inpatients or outpatients who consult at the Malahayati Islamic Hospital or the University of North Sumatra Hospital, both middle and upper-middle class. Because the density level of occupants in hospital buildings is high, it requires a fire ladder that meets the standards, how to apply the fire ladder reliability system and its future recommendations on the Malahayati Islamic Hospital building and the University of North Sumatra Hospital. This study aims to determine the application and analyze the level of reliability of fire stairs in hospital buildings. This study uses data analysis method, namely AHP (Analytical Hierarchy Process) which is based on very effective research to help solve problems in the fire stairs reliability system in the case study of the Islamic Hospital Malahayati, the level of reliability is sufficient, while the University of North Sumatra Hospital has a very good level of reliability. Several design recommendations were made and tested to increase the reliability of fire stairs at Malahayati Islamic Hospital and the University of North Sumatra Hospital; the results can be improved.
\end{abstract}

Keyword: Fire Stairs, hospital, passive protection system

\section{Introduction}

Development in Medan City is increasing at this time; many building developments are diverse and complex demanding aspects of safety and security for the building and its environment. Fires can cause death and can cause harmful structural collapse. Some of the causes of fire include low understanding and public awareness of fire hazards, fire management systems that have not been realized and integrated, low infrastructure and facilities for adequate building fire protection systems. Based on constitution No. 44 of 2009 concerning hospitals, what is meant by a hospital is a health service institution that carries out complete individual health services that provide inpatient, outpatient and emergency services [1].

Based on constitution No. 44 of 2009 concerning hospitals, what is meant by a hospital is a health service institution that carries out complete individual health services that provide inpatient, outpatient and emergency services. Based on the above problems, the researcher will

*Corresponding author at: Departement of Architecture, Faculty of Engineering, Universitas Sumatera Utara,

Street Perpustakaan Building J07, Medan, Indonesia

E-mail address: zilisa96@gmail.com 
examine the hospital buildings in Medan, namely the Malahayati Islamic Hospital and the University of North Sumatra Hospital located in Medan City. This hospital is classified as very crowded because of the number of inpatients or outpatients. Because the density level of occupants in hospital buildings is high, it requires a fire ladder that meets the standards, how to apply the fire ladder-reliability system in the Malahayati Islamic Hospital building and the University of North Sumatra Hospital which is good so that the evacuation process runs effectively and efficiently.

\section{Literature Review}

Fire

Definition of fire according to NFPA (National Fire Protection Association) fire is an oxidation event that involves three elements that must exist, namely; combustible fuels, oxygen in the air, and heat or energy sources that result in property loss, injury and even human death [2].

In NFPA, there are six classifications namely fires types A, B, C, D, E, and K. Fire classification according to NFPA, following in table 1.

Table 1. Fire Classification according to NFPA.

\begin{tabular}{lll}
\hline Types & Fire & Extinguisher \\
\hline Non Metal Solid & Paper, Fabric, Plastic, \\
Wood & Water, Steam, Sand, Foam, CO2, Dry \\
Chemical Powder, Chemical Liquid
\end{tabular}

(Source: NFPA, 1999)

Building

Building according to the Minister of Public Works Number 45 / PRT / M / 2007 is a physical form of the results of construction work that integrates with the place and position, partially or entirely above and know in the soil or water, which serves as a place for people to do activities, both for shelter or residence, religious activities, business activities, social activities, cultural activities and special activities.. 
Hospital

According to WHO (1957), mentioning that hospitals by the World Health Organization are given limitations, namely a comprehensive part of the organization and medical, functioning to provide complete health services to both curative and rehabilitative communities, where the services reach family and environmental services, hospitals are also health personnel training center and biosocial research.

Passive Fire Protection Facilities

According to the Minister of Public Works Regulation No. 26 / PRT / M / 2008, passive fire protection systems are fire protection systems that are formed or built through regulation of the use of materials and components of building structures, compartmentalization or separation of buildings on fire resistance levels, as well as protection against openings [3].

\section{Rescue Facility}

Rescue facilities are means prepared for use by residents and fire fighting officers to save the lives of humans and property in the event of a fire in a building and environment. The purpose of the rescue facility is to prevent accidents or injuries when evacuating when an emergency road occurs (Minister of Public Works Regulation No. 26 / PRT / M / 2008).

\section{Standard Fire Stairs}

Fire ladders in high rise buildings must meet the applicable standards. Standard fire stairs specified in SNI 03-1746 - 2000 (Table 2).

Table 2. New and Existing Fire Ladder Standards

\begin{tabular}{|c|c|c|}
\hline \multicolumn{3}{|c|}{ Standard : The New Ladder } \\
\hline $\begin{array}{l}\text { Net width of obstacles, except bumps in or } \\
\text { below the height of handrails on each side } \\
\text { to no more than } 9 \mathrm{~cm}\end{array}$ & \multicolumn{2}{|c|}{$\begin{array}{l}110 \text { centimeters ( } 44 \text { inches), } 90 \mathrm{~cm} \text { ( } 36 \text { inches), } \\
\text { if the total load of all residential floors } \\
\text { are served by line ladder less than } 50\end{array}$} \\
\hline The maximum height of the stairs & \multicolumn{2}{|c|}{$18 \mathrm{~cm}$ (7 inches) } \\
\hline The minimum height of the stairs & \multicolumn{2}{|c|}{$10 \mathrm{~cm}$ (4 inches) } \\
\hline The minimum depth of steps & \multicolumn{2}{|c|}{$28 \mathrm{~cm}$ (11 inches) } \\
\hline Minimum room height & \multicolumn{2}{|c|}{$200 \mathrm{~cm},(6 \mathrm{ft}, 8$ inches $)$} \\
\hline $\begin{array}{l}\text { Maximum height between } \\
\text { bordes ladder }\end{array}$ & \multicolumn{2}{|c|}{$3,7 \mathrm{~m}(12 \mathrm{ft})$} \\
\hline \multirow[t]{3}{*}{ Bordes ladder } & \multicolumn{2}{|c|}{ See grain 5.1.3 and 5.1.4.4. } \\
\hline & ting Stairs & \\
\hline & Class A & Class B \\
\hline \multirow{2}{*}{$\begin{array}{l}\text { Net width of obstacles, except bumps in or } \\
\text { below the height of handrails on each side } \\
\text { to no more than } 9 \mathrm{~cm}\end{array}$} & $110 \mathrm{~cm}$ (44 inches) & $110 \mathrm{~cm}$ (44 inches) \\
\hline & \multicolumn{2}{|c|}{$\begin{array}{l}90 \mathrm{~cm} \text { ( } 36 \text { inches), if the total load of all } \\
\text { residential floors are served by line } \\
\text { ladder less than } 50 \mathrm{~cm}\end{array}$} \\
\hline The maximum height of the stairs & $19 \mathrm{~cm}\left(7 \frac{1}{2}\right.$ inches $)$ & $20 \mathrm{~cm}$ (8 inches) \\
\hline The minimum depth of steps & $25 \mathrm{~cm}$ ( 10 inches) & $23 \mathrm{~cm}$ (9 inches) \\
\hline Minimum room height & $200 \mathrm{~cm}$ ( $6 \mathrm{ft}, 8$ inches $)$ & $200 \mathrm{~cm}$ ( $6 \mathrm{ft}, 8$ inches $)$ \\
\hline Maximum height between ladder bordes & $3,7 \mathrm{~m}(12 \mathrm{ft})$ & $3,7 \mathrm{~m}(12 \mathrm{ft})$ \\
\hline Bordes ladder & \multicolumn{2}{|c|}{ See grain 5.1.3 and 5.1.4.4 } \\
\hline
\end{tabular}




\section{A Term of Handrail Rail Stairs}

In the details of the handrail, there are some that must be seen on the fire ladder, namely: Height of stairs on the stairs Min. $86 \mathrm{~cm}$ and max. $100 \mathrm{~cm}$ above the surface of the stairs, the Handrail material is made of iron, and the handrail distance between the borders is at least easy to reach for its users (Figure 1).

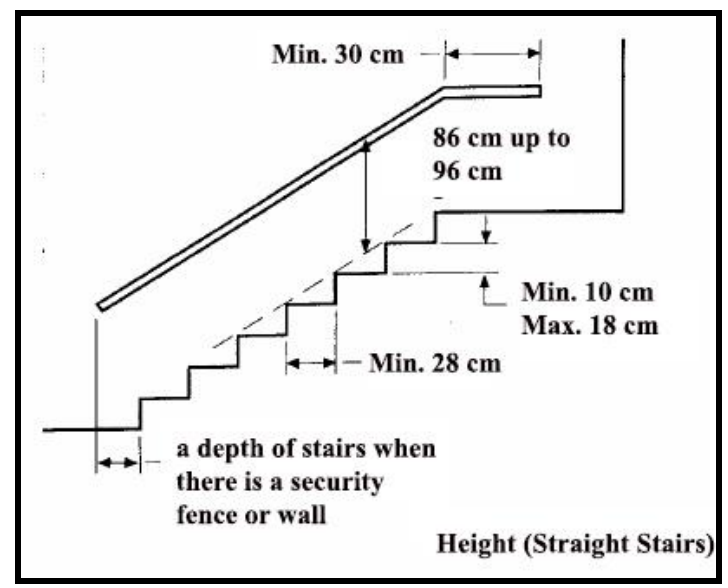

Figure 1. A Term of Handrail

Analytical Hierarchy Process (AHP)

AHP is a decision support method developed by a University of Pittsburgh-born professor of mathematics from Iraq, Thomas L. AHP is a method for making a sequence of decision alternatives and selecting the best alternative when decision-makers with several objectives or criteria for making certain decisions. The most important thing in AHP is a functional hierarchy with its main input is human perception. With a hierarchy, a complex and unstructured problem can be solved into the group, then the groups are arranged into a hierarchical form.

\section{Methodology}

This study discusses the analysis of the reliability of emergency stairs in the Malahayati Islamic Hospital building and the University of North Sumatra Hospital, so the type of research used is descriptive, comparative, qualitative and quantitative research, where the data obtained from theoretical studies and observations/surveys of buildings This will be compiled and analyzed to get the conclusion from this research. The final result of this study is a good fire stair recommendation.

Then the next step is to determine each variable and sub-variable of the research on the emergency ladder to find out the existing conditions in each case study of the hospital building (Table 3). 
Table 3. Variables and Sub - Research Variables

\begin{tabular}{|c|c|c|}
\hline \multirow{4}{*}{ Fire Stairs } & Yariabel & Sub - Variabel \\
\hline & $\begin{array}{l}\text { The Existence of } \\
\text { The Ladder }\end{array}$ & $\begin{array}{l}\text { - Number of Stairs } \\
\text { - Distance of Achievement } \\
\text { - Type of Stairs } \\
\text { - Access Building Exits from Fire Stairs }\end{array}$ \\
\hline & Stairs Construction & $\begin{array}{l}\text { - Stairs are Protected by Fireproof } \\
\text { Seperation Walls } \\
\text { - The Ladder is Protected by a Smoke } \\
\text { Resistant Seperator } \\
\text { - Width of The Stairs } \\
\text { - Wide Stepping Lader of The Stair } \\
\text { - Stairs Height } \\
\text { - Distance of Stairs Between Borders }\end{array}$ \\
\hline & $\begin{array}{l}\text { Completeness of } \\
\text { Stairs }\end{array}$ & $\begin{array}{l}\text { - Handrail } \\
\text { - Signage } \\
\text { - Emergency Lighting }\end{array}$ \\
\hline
\end{tabular}

To determine the weight and reliability value of Fire Emergency Stairs in Hospital Buildings can be seen in the following stages:

An Ordering of Interests for each Sub - Variable

All sub-variables are given criteria of importance to rank them, the criteria used are to see how important one sub-variable is to another sub-variable in a passive fire protection system on the emergency ladder

Weighting

After each sub-variable is given a value, the next step is to find the weight of each sub-variable by creating a matrix. In this matrix calculation, researchers use Ms.'s application. Office Excel with nine references of importance weight as follows based on Saaty's theory (Table 4).

Table 4. Scale table of sub-variables of interest Ms. AHP Method Office Excel

\begin{tabular}{cc}
\hline Value & Information \\
\hline 1 & A is equally important with criterion B \\
\hline 3 & A is slightly more important than B \\
\hline 5 & A is definitely more important than B \\
\hline 7 & A very clearly more important than B \\
\hline 9 & A absolute is more important than B \\
\hline $2,4,6,8$ & When in doubt between two adjacent values \\
\hline
\end{tabular}


Assessment of Building Safety System Reliability Values

To provide the value of each variable based on the availability of these variables in the object of research. The following criteria for evaluating the availability of variables are as follows (Table 5) :

Table 5. The Scale of The Fire Stairs Component Reliability.

\begin{tabular}{ccc}
\hline No. & $\begin{array}{c}\text { Reliability Value } \\
\text { of Sub-Variables in } \\
\text { The Case Study }\end{array}$ & Information \\
\hline 1. & 1 & $\begin{array}{c}\text { it has absolutely no components according } \\
\text { to reliability requirements }\end{array}$ \\
\hline 2. & 2 & $\begin{array}{c}\text { Have components but all do not match } \\
\text { reliability requirements }\end{array}$ \\
\hline 3. & 3 & $\begin{array}{c}\text { Has some components that match } \\
\text { reliability requirements }\end{array}$ \\
\hline 4. & 4 & All components conform to reliability \\
requirements
\end{tabular}

Determining The Rating Scale

The final stage is to determine the passive fire protection system rating scale (Table 6)

Table 6. Value of Fire Relief Assessment Rating

\begin{tabular}{ccc}
\hline $\begin{array}{c}\text { Reliability of Fire Ladder } \\
\text { Value }\end{array}$ & Information & Recommendation \\
\hline $1 \leq \mathrm{x} \leq 1,6$ & Bad & $\begin{array}{c}\text { Redesign According to } \\
\text { applicable standards }\end{array}$ \\
\hline $1,61 \leq \mathrm{x} \leq 2,2$ & Less & Complete Less Components \\
\hline $2,21 \leq \mathrm{x} \leq 2,8$ & Enough & Emergency Stair Care and Repair \\
\hline $2,81 \leq \mathrm{x} \leq 3,4$ & Well & Periodic Inspection and Repair \\
\hline $3,41 \leq \mathrm{x} \leq 4$ & Very Good & Periodic Treatment \\
\hline
\end{tabular}

\section{Result and Discussion}

Research Location Data

Malahayati Islamic Hospital was established in 1974 and began operation in 1975. This hospital is a type $\mathrm{C}$ hospital. The area that became the research site in the form of the Malahayati Hospital building site on the street Pangeran Diponegoro No. 2-4 Medan, covering an area of \pm $7,500 \mathrm{~m}^{2}$. This hospital is a type C hospital. On July 18, 2017, the Islamic Hospital Malahayati successfully-passed PARIPURNA accreditation (Figure 2). 


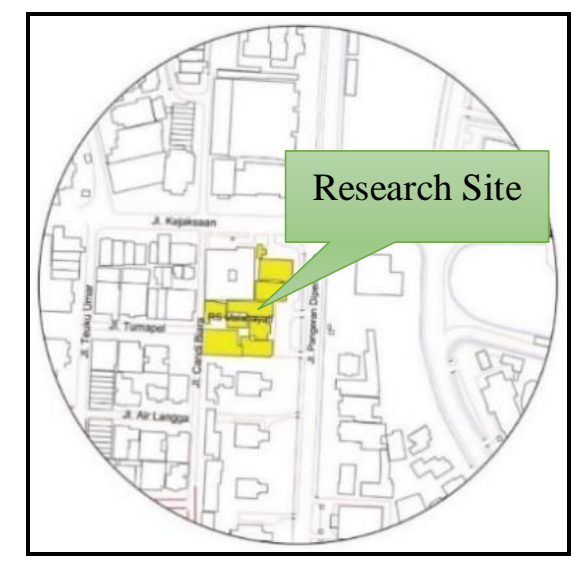

Figure 2. Malahayati Islamic Hospital Location Map

The following are the results of a survey of conditions of emergency stairs at the University of North Sumatra Hospital (Figure 3).

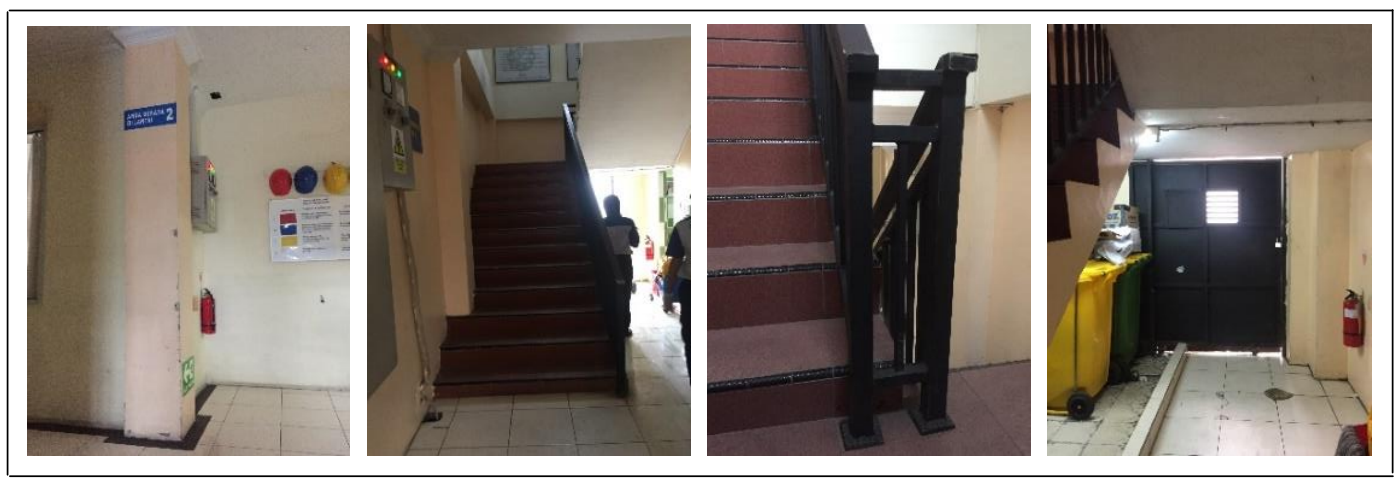

Figure 3. Existing Condition of Malahayati Islamic Hospital.

The area that became the place of research was the building of the University of North Sumatra Hospital site on the street Dr. Mansyur No.66, Merdeka, Medan Baru, Medan City, North Sumatra 20154. This hospital is a type C hospital. On December 28, 2016, the University of North Sumatra Hospital succeeded in achieving PARIPURNA accreditation (Figure 4).

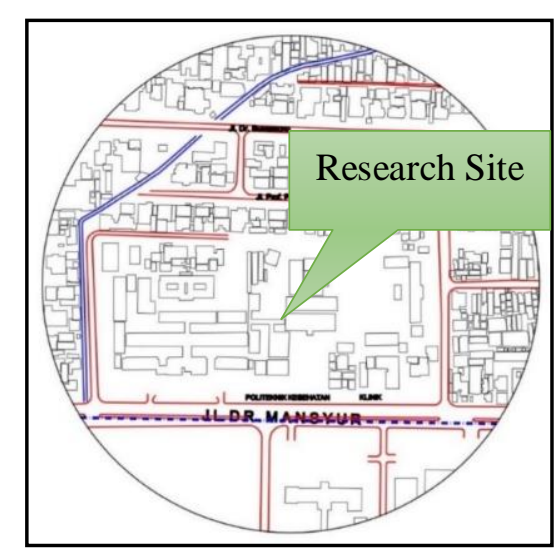

Figure 4. University of North Sumatra Hospital Location Map 
The following are the results of a survey of conditions of emergency stairs at the University of North Sumatra Hospital (Figure 5):
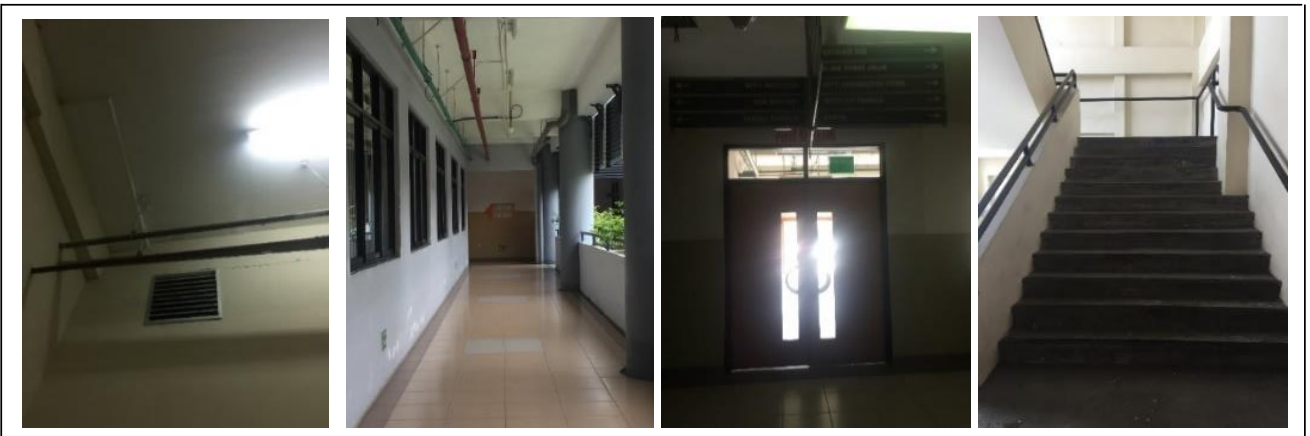

Figure 5. Existing Condition of the University of North Sumatra Hospital.

As for the results of processing the AHP Method with Ms. Application Office Excel based on the sequence of work steps is as follows:

Sort Each Variable and Sub - Variable

The following is the order of importance to get the results of the rating scale (Table 7) :

Table 7. Table of Interest Sequences for each Variable and Sub Variable.

\begin{tabular}{|c|c|c|}
\hline $\begin{array}{c}\text { Serial } \\
\text { Number }\end{array}$ & Code & Variable \\
\hline 1 & A & Construction Stairs \\
\hline 2 & B & The Existence of Stairs \\
\hline \multirow[t]{18}{*}{3} & $\mathrm{C}$ & Completeness Stairs \\
\hline & $\begin{array}{c}\text { Serial } \\
\text { Number }\end{array}$ & Sub - Variable \\
\hline & & A. Construction Stairs \\
\hline & $1 \mathrm{~A}$ & $\begin{array}{l}\text { Stairs are Protected by Fireproof } \\
\text { Seperation Walls }\end{array}$ \\
\hline & $2 \mathrm{~A}$ & $\begin{array}{l}\text { The Ladder is Protected by a Smoke } \\
\text { Resistant Seperator }\end{array}$ \\
\hline & $3 \mathrm{~A}$ & Width of The Stairs \\
\hline & $4 \mathrm{~A}$ & Wide Stepping Ladder of The Stairs \\
\hline & $5 \mathrm{~A}$ & Stairs Height \\
\hline & $6 \mathrm{~A}$ & Distance of Stairs Between Borders \\
\hline & & B. The Existence of Stairs \\
\hline & 1B & Access Building Exits from Fire Stairs \\
\hline & $2 \mathrm{~B}$ & Distance of Achievement \\
\hline & $3 \mathrm{~B}$ & Number of Stairs \\
\hline & 4B & Type of Stairs \\
\hline & & C. Completeness Stairs \\
\hline & $1 \mathrm{C}$ & Emergency Lighting \\
\hline & $2 \mathrm{C}$ & Signage \\
\hline & $3 \mathrm{C}$ & Handrail \\
\hline
\end{tabular}


The following stages calculate the weight of each variable to get the percentage of each variable: (1) To determine the valuation of the importance of each variable or sub-variable assisted by reference to filling in a matrix that is appropriate to the existing conditions of the hospital emergency ladder during the survey (Table 8).

Table 8. Variable and Sub-Variable Interest Scale

\begin{tabular}{cc}
\hline Value & Information \\
\hline 1 & A is equally important with criterion B \\
\hline 3 & A is slightly more important than B \\
\hline 5 & A is definitely more important than B \\
\hline 7 & A very clearly more important than B \\
\hline 9 & A absolute is more important than B \\
\hline $2,4,6,8$ & When in doubt between two adjacent values \\
\hline
\end{tabular}

(2) After determining the valuation of interests in the variables, the next step is by examining the initial comparison (Table 9).

Table 9. Calculation of the initial matrix of Variable interests.

\begin{tabular}{c|c|c|c}
\hline & $\mathrm{A}$ & $\mathrm{B}$ & $\mathrm{C}$ \\
\hline $\mathrm{A}$ & 1,00 & 1,00 & 2,00 \\
\hline $\mathrm{B}$ & 1,00 & 1,00 & 1,00 \\
\hline $\mathrm{C}$ & 0,50 & 1,00 & 1,00 \\
\hline TOTAL & 2,50 & 3,00 & 4,00 \\
\hline
\end{tabular}

(3) After calculating the initial matrix which is given the value of each variable's importance, then normalization of the comparison (Table 10).

Table 10. Comparative normalization matrix for variable interests

\begin{tabular}{|c|c|c|c|c|c|c|c}
\hline & A & B & C & $\begin{array}{c}\text { The } \\
\text { Number of } \\
\text { Rows in }\end{array}$ & $\begin{array}{c}\text { Periority } \\
\text { Vector }\end{array}$ & $\begin{array}{c}\text { While } \\
\text { Weighting }\end{array}$ & $\begin{array}{c}\text { The } \\
\text { Final } \\
\text { Weighting }\end{array}$ \\
\hline A & 0,40 & 0,33 & 0,50 & 1,23 & 0,41 & 1,26 & 0,41 \\
\hline B & 0,40 & 0,33 & 0,25 & 0,98 & 0,33 & 1,00 & 0,33 \\
\hline C & 0,20 & 0,33 & 0,25 & 0,78 & 0,26 & 0,79 & 0,26 \\
\hline TOTAL & 1,00 & 1,00 & 1,00 & 3,00 & & 3,06 & 1 \\
\hline
\end{tabular}

After calculating the initial matrix and the normalization matrix comparing the interests of each variable, then calculating the weight of each sub-variable to get the weight percent of the subvariables that have been sorted out (Table 11). 
Table 11. The initial matrix is the comparison and normalization of the sub-variables of the Stair Construction variable (Variable A).

\begin{tabular}{c|c|c|c|c|c|c|}
\hline & $1 \mathrm{~A}$ & $2 \mathrm{~A}$ & $3 \mathrm{~A}$ & $4 \mathrm{~A}$ & $5 \mathrm{~A}$ & $6 \mathrm{~A}$ \\
\hline $1 \mathrm{~A}$ & 1,00 & 6,00 & 7,00 & 5,00 & 4,00 & 5,00 \\
\hline $2 \mathrm{~A}$ & 0,17 & 1,00 & 9,00 & 7,00 & 5,00 & 4,00 \\
\hline $3 \mathrm{~A}$ & 0,14 & 0,11 & 1,00 & 1,00 & 2,00 & 3,00 \\
\hline $4 \mathrm{~A}$ & 0,20 & 0,14 & 1,00 & 1,00 & 1,00 & 3,00 \\
\hline $5 \mathrm{~A}$ & 0,25 & 0,20 & 0,50 & 1,00 & 1,00 & 1,00 \\
\hline $6 \mathrm{~A}$ & 0,20 & 0,25 & 0,33 & 0,33 & 1,00 & 1,00 \\
\hline TOTAL & 1,96 & 7,70 & 18,83 & 15,33 & 14,00 & 17,00 \\
\hline
\end{tabular}

\begin{tabular}{|c|c|c|c|c|c|r|r|r|r|c|}
\hline & $1 \mathrm{~A}$ & $2 \mathrm{~A}$ & $3 \mathrm{~A}$ & $4 \mathrm{~A}$ & $5 \mathrm{~A}$ & $6 \mathrm{~A}$ & $\begin{array}{c}\text { The } \\
\text { Number of } \\
\text { Rows in }\end{array}$ & $\begin{array}{c}\text { Periority } \\
\text { Vector }\end{array}$ & $\begin{array}{c}\text { While } \\
\text { Weighting }\end{array}$ & $\begin{array}{c}\text { The } \\
\text { Final } \\
\text { Weighting }\end{array}$ \\
\hline 1A & 0,51 & 0,78 & 0,37 & 0,33 & 0,29 & 0,29 & 2,57 & $0,43^{\prime}$ & 3,69 & 0,48 \\
\hline 2A & 0,09 & 0,13 & 0,48 & 0,46 & 0,36 & 0,24 & 1,74 & $0,29^{\prime}$ & 2,23 & 0,29 \\
\hline $3 \mathrm{~A}$ & 0,07 & 0,01 & 0,05 & 0,07 & 0,14 & 0,18 & 0,52 & $0,09^{\prime}$ & 0,54 & 0,07 \\
\hline 4A & 0,10 & 0,02 & 0,05 & 0,07 & 0,07 & 0,18 & 0,49 & $0,08^{\prime}$ & 0,51 & 0,07 \\
\hline $5 \mathrm{~A}$ & 0,13 & 0,03 & 0,03 & 0,07 & 0,07 & 0,06 & 0,38 & $0,06^{\prime}$ & 0,40 & 0,05 \\
\hline $6 \mathrm{~A}$ & 0,10 & 0,03 & 0,02 & 0,02 & 0,07 & 0,06 & 0,30 & $0,05^{\prime \prime}$ & 0,33 & 0,04 \\
\hline TOTAL & 1,00 & 1,00 & 1,00 & 1,00 & 1,00 & 1,00 & 6,00 & & 7,70 & 1,00 \\
\hline
\end{tabular}

After getting the percent weighting of variable construction stairs then calculate the weight of each variable is the existence of stairs (Table 12).

Table 12. The initial matrix is the comparison and normalization of the sub-variables of the Ladder Existence variable (Variable B).

\begin{tabular}{c|c|c|c|c|}
\hline & $1 \mathrm{~B}$ & $2 \mathrm{~B}$ & $3 \mathrm{~B}$ & $4 \mathrm{~B}$ \\
\hline 1B & 1,00 & 5,00 & 5,00 & 3,00 \\
\hline 2B & 0,20 & 1,00 & 5,00 & 2,00 \\
\hline 3B & 0,20 & 0,20 & 1,00 & 2,00 \\
\hline 4B & 0,33 & 0,50 & 0,50 & 1,00 \\
\hline TOTAL & 1,73 & 6,70 & 11,50 & 8,00 \\
\hline
\end{tabular}

\begin{tabular}{c|c|c|c|c|r|r|r|r|}
\hline & 1B & 2B & 4B & 5B & $\begin{array}{c}\text { The } \\
\text { Number of } \\
\text { Rows in }\end{array}$ & $\begin{array}{c}\text { Periority } \\
\text { Vector }\end{array}$ & $\begin{array}{c}\text { While } \\
\text { Weighting }\end{array}$ & $\begin{array}{c}\text { The } \\
\text { Final } \\
\text { Weighting }\end{array}$ \\
\hline 1B & 0,58 & 0,75 & 0,43 & 0,38 & 2,13 & 0,53 & 2,65 & 0,77 \\
\hline 2B & 0,12 & 0,15 & 0,43 & 0,25 & 0,95 & 0,24 & 0,71 & 0,21 \\
\hline 3B & 0,12 & 0,03 & 0,09 & 0,25 & 0,48 & 0,12 & 0,05 & 0,01 \\
\hline 4B & 0,19 & 0,07 & 0,04 & 0,13 & 0,44 & $0,11^{\prime}$ & 0,04 & 0,01 \\
\hline TOTAL & 1,00 & 1,00 & 1,00 & 1,00 & 4,00 & & 3,44 & 1,00 \\
\hline
\end{tabular}

After calculating the initial matrix and normalizing the variable existence of the ladder-finally, calculate the variable ladder completeness (Table 13). 
Table 13. The initial matrix is the comparison and normalization of sub-variables of the Ladder Completion variable (Variable C)

\begin{tabular}{c|c|c|c}
\hline & $1 \mathrm{C}$ & $2 \mathrm{C}$ & $3 \mathrm{C}$ \\
\hline $1 \mathrm{C}$ & 1,00 & 1,00 & 3,00 \\
\hline $2 \mathrm{C}$ & 1,00 & 1,00 & 5,00 \\
\hline $3 \mathrm{C}$ & 0,33 & 0,20 & 1,00 \\
\hline TOTAL & 2,33 & 2,20 & 9,00 \\
\hline
\end{tabular}

\begin{tabular}{cc|c|r|rr|r|r}
\hline & $1 \mathrm{C}$ & $2 \mathrm{C}$ & $3 \mathrm{C}$ & $\begin{array}{c}\text { The } \\
\text { Number of } \\
\text { Rows in }\end{array}$ & $\begin{array}{c}\text { Periority } \\
\text { Vector }\end{array}$ & $\begin{array}{c}\text { While } \\
\text { Weighting }\end{array}$ & $\begin{array}{c}\text { The } \\
\text { Final } \\
\text { Weighting }\end{array}$ \\
\hline 1C & 0,43 & 0,45 & 0,33 & 1,22 & $0,41^{\prime}$ & 1,23 & 0,66 \\
\hline 2C & 0,43 & 0,45 & 0,56 & 1,44 & $0,48^{\prime}$ & 0,59 & 0,32 \\
\hline 3C & 0,14 & 0,09 & 0,11 & 0,34 & $0,11^{\prime}$ & 0,04 & 0,02 \\
\hline TOTAL & 1,00 & 1,00 & 1,00 & 3,00 & & 1,86 & 1,00 \\
\hline
\end{tabular}

Data Processing to determine Reliability Value

So the last stage is processing data from the results of the percent weight of sub-variables to determine the reliability value of each case study of the Malahayati Islamic Hospital building (Table 14).

Table 14. Malahayati Islamic Hospital Data Processing.

\begin{tabular}{|c|c|c|c|c|c|c|}
\hline No. & Sub-Varibels & $\begin{array}{l}\text { While } \\
\text { Weighing }\end{array}$ & $\begin{array}{c}\text { The Value } \\
\text { of } \\
\text { Avaliability }\end{array}$ & $\begin{array}{l}\text { Provisional } \\
\text { Value } \mathrm{X} \\
\text { Weighting } \\
\text { Availability } \\
(n)\end{array}$ & $\begin{array}{c}\text { Total } \\
n\end{array}$ & $\begin{array}{c}\text { Value } \\
n\end{array}$ \\
\hline & A. Stairs Construction & 0,41 & & & & \\
\hline $1 \mathrm{~A}$ & The Stairs are Protected by a Fire Separat, & 0,48 & 1 & 0,48 & \multirow{6}{*}{1,69} & \multirow{6}{*}{0,70} \\
\hline $2 \mathrm{~A}$ & Protected by Smoke-proof Stairwells & 0,29 & 1 & 0,29 & & \\
\hline $3 \mathrm{~A}$ & Width of Stairs & 0,07 & 4 & 0,28 & & \\
\hline $4 \mathrm{~A}$ & Width of Stepping Stairs & 0,07 & 4 & 0,26 & & \\
\hline $5 \mathrm{~A}$ & Stair Height & 0,05 & 4 & 0,21 & & \\
\hline \multirow[t]{2}{*}{$6 \mathrm{~A}$} & Distance Between Borders & 0,04 & 4 & 0,17 & & \\
\hline & B. The Presence of Stairs & 0,33 & & & & \\
\hline $1 \mathrm{~B}$ & Access to Building Exits & 0,77 & 4 & 3,08 & \multirow{4}{*}{3,99} & \multirow{4}{*}{1,30} \\
\hline $2 B$ & Distance of Achievement & 0,21 & 4 & 0,83 & & \\
\hline $3 B$ & The Number of Stairs & 0,01 & 3 & 0,04 & & \\
\hline \multirow[t]{2}{*}{$4 B$} & Types of Stairs & 0,01 & 4 & 0,04 & & \\
\hline & C. The Completeness of The Stairs & 0,26 & & & & \\
\hline $1 \mathrm{C}$ & Emergency Lighting & 0,66 & 2 & 1,32 & \multirow{3}{*}{2,34} & \multirow{3}{*}{0,61} \\
\hline $2 \mathrm{C}$ & Signage & 0,32 & 3 & 0,96 & & \\
\hline \multirow[t]{2}{*}{$3 \mathrm{C}$} & Handrail & 0,02 & 3 & 0,06 & & \\
\hline & & & & & & 2,61 \\
\hline
\end{tabular}

After searching for the value of reliability in Islamic hospitals, instead, it then calculated the value of reliability in the North Sumatra University Hospital building. By calculating the results of the weight multiplied by the value of availability in accordance with the conditions of the emergency stairs in each case study of the hospital building studied, then summing the total then the total value of reliability divided by the number of variables can be known the average value of sub-variables (Table 15). 
Table 15. University of North Sumatera Hospital Data Processing.

\begin{tabular}{|c|c|c|c|c|c|c|}
\hline No. & Sub-Varibels & $\begin{array}{c}\text { While } \\
\text { Weighing }\end{array}$ & $\begin{array}{l}\text { The Value of } \\
\text { Availability }\end{array}$ & $\begin{array}{l}\text { Amount }= \\
\text { Provisional } \\
\text { Value X } \\
\text { Weighing } \\
\text { Availability } \\
(n)\end{array}$ & $\begin{array}{c}\text { Total } \\
n\end{array}$ & $\begin{array}{c}\text { Value } \\
n\end{array}$ \\
\hline & A. Stairs Construction & 0,41 & & & & \\
\hline $1 \mathrm{~A}$ & The Stairs are Protected by a Fire Separat & 0,48 & 4 & 1,92 & \multirow{6}{*}{3,65} & \multirow{6}{*}{1,51} \\
\hline $2 \mathrm{~A}$ & Protected by Smoke-proof Stairwells & 0,29 & 4 & 1,16 & & \\
\hline $3 \mathrm{~A}$ & Width of Stairs & 0,07 & 3 & 0,21 & & \\
\hline $4 \mathrm{~A}$ & Width of Stepping Stairs & 0,07 & 2 & 0,13 & & \\
\hline $5 \mathrm{~A}$ & Stair Height & 0,05 & 2 & 0,10 & & \\
\hline \multirow[t]{2}{*}{$6 \mathrm{~A}$} & Distance Between Borders & 0,04 & 3 & 0,13 & & \\
\hline & B. The Presence of Stairs & 0,33 & & & & \\
\hline 18 & Access to Building Exits & 0,77 & 4 & 3,08 & \multirow{4}{*}{3,79} & \multirow{4}{*}{1,24} \\
\hline $2 \mathrm{~B}$ & Distance of Achievement & 0,21 & 3 & 0,62 & & \\
\hline $3 B$ & The Number of Stairs & 0,01 & 4 & 0,05 & & \\
\hline \multirow[t]{2}{*}{$4 B$} & Types of Stairs & 0,01 & 4 & 0,04 & & \\
\hline & C. The Completeness of The Stairs & 0,26 & & & & \\
\hline $1 \mathrm{C}$ & Emergency Lighting & 0,66 & 4 & 2,64 & \multirow{3}{*}{3,34} & \multirow{3}{*}{0,87} \\
\hline $2 \mathrm{C}$ & Signage & 0,32 & 2 & 0,64 & & \\
\hline \multirow[t]{2}{*}{$3 C$} & Handrail & 0,02 & 3 & 0,06 & & \\
\hline & & & & & & 3,62 \\
\hline
\end{tabular}

From the results of the above calculations, then compared with the value of the comparison scale. As follows in Table 16 :

Table 16. Value of Reliability Assessment.

\begin{tabular}{ccc}
$\begin{array}{c}\text { of The Reliability } \\
\text { Ladder Fire }\end{array}$ & Description & Recommendations \\
\hline $1 \leq \mathrm{x} \leq 1,6$ & Bad & $\begin{array}{c}\text { Redesign Sccording } \\
\text { to Standards in Force }\end{array}$ \\
\hline $1,61 \leq \mathrm{x} \leq 2,2$ & Less & $\begin{array}{c}\text { Complement Components } \\
\text { are Less }\end{array}$ \\
\hline $2,21 \leq \mathrm{x} \leq 2,8$ & Enough & $\begin{array}{c}\text { Maintenance and Repair } \\
\text { of Emergency Stairs }\end{array}$ \\
\hline $2,81 \leq \mathrm{x} \leq 3,4$ & Good & $\begin{array}{c}\text { Inspection and Repair } \\
\text { Periodically }\end{array}$ \\
\hline $3,41 \leq \mathrm{x} \leq 4$ & Very Good & Regular Maintenance \\
\hline
\end{tabular}

\section{Conclusion}

This study uses the Analytical Hierarchy Process (AHP) method; this method is very effective in solving problems in decision support systems that are very easy and appropriate for users of other academic communities. Recommendations for improvement in improving the reliability of fire stairs : (a) Malahayati Islamic Hospital, the level of emergency stairs reliability, some subvariables do not meet the requirements: Wall Protected by Fire Separator (bad), SmokeResistant (bad), and Emergency Exits (bad) (Figure 6). (b) From the results of the analysis on 
the fire ladder by using the Analytical Hierarchy Process (AHP) method, the design of the fire staircase, so that the reliability level of the fire stairs is better, i.e., from 2.61 to 3.86 (Table 17).

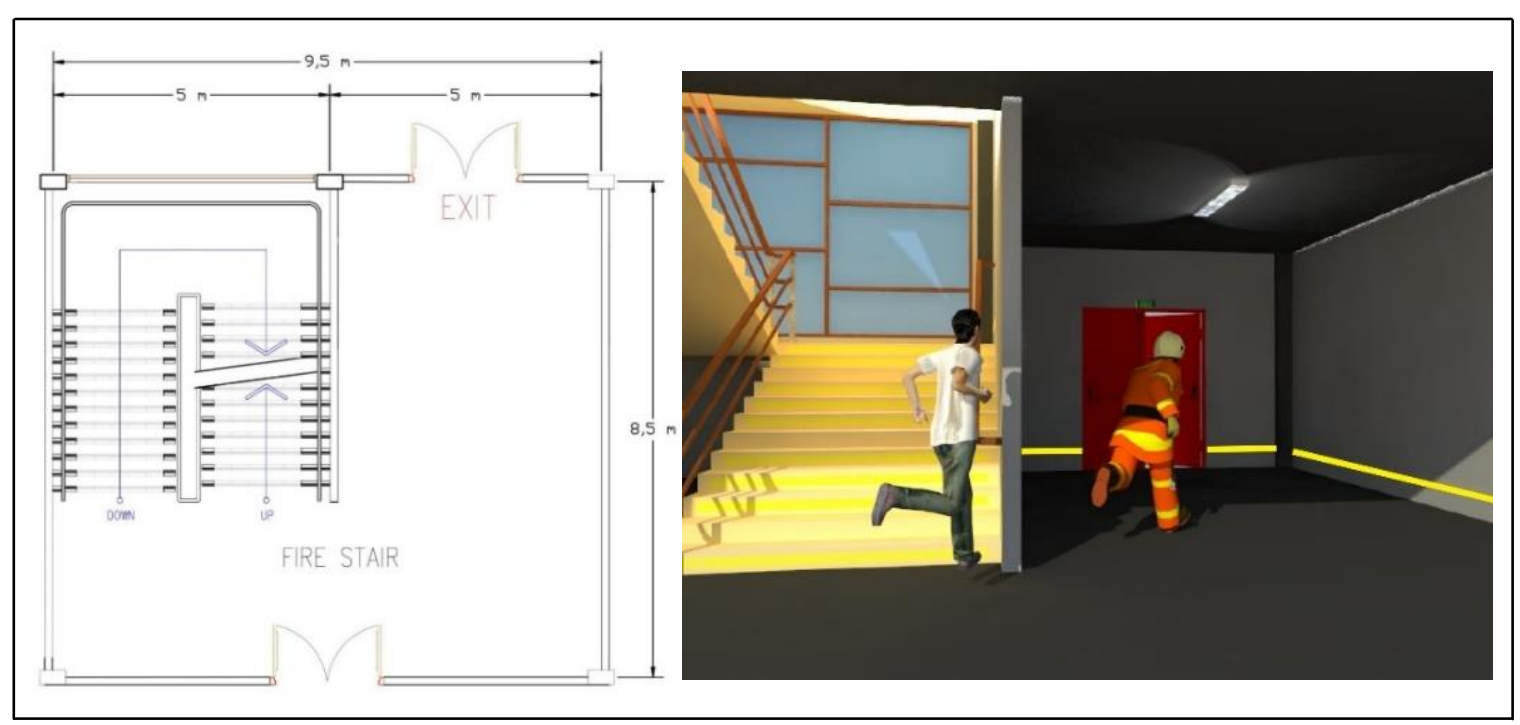

Figure 6. Proposed Design of Malahayati Islamic Hospital Emergency Ladder Plan

University of North Sumatra Hospital, the level of reliability of the emergency stairs several sub-variables do not meet the requirements: (1) Signage (bad) If the signage inside the emergency staircase is added the requirements, then the level of reliability of the fire stairs is very good, from 3.62 to 3.86 (Table 15 to Table 17).

Table 17. Table of Reliability Score for Emergency Stairs of the University of North Sumatra Hospital.

\begin{tabular}{|c|c|c|c|c|c|c|}
\hline No. & Sub-Varibels & $\begin{array}{c}\text { While } \\
\text { Weighing }\end{array}$ & $\begin{array}{l}\text { The Value } \\
\text { of } \\
\text { Availability }\end{array}$ & $\begin{array}{l}\text { Amount }= \\
\text { Provisional } \\
\text { Value X } \\
\text { Weighing } \\
\text { Availability } \\
(n)\end{array}$ & $\begin{array}{c}\text { Total } \\
n\end{array}$ & $\begin{array}{c}\text { Value } \\
n\end{array}$ \\
\hline & A. Stairs Construction & 0,41 & & & & \\
\hline $1 \mathrm{~A}$ & The Stairs are Protected by a Fire Separat & 0,48 & 4 & 1,92 & \multirow{6}{*}{3,88} & \multirow{6}{*}{1,60} \\
\hline $2 \mathrm{~A}$ & Protected by Smoke-proof Stairwells & 0,29 & 4 & 1,16 & & \\
\hline $3 \mathrm{~A}$ & Width of Stairs & 0,07 & 4 & 0,28 & & \\
\hline $4 \mathrm{~A}$ & Width of Stepping Stairs & 0,07 & 3 & 0,20 & & \\
\hline $5 \mathrm{~A}$ & Stair Height & 0,05 & 3 & 0,16 & & \\
\hline \multirow[t]{2}{*}{$6 \mathrm{~A}$} & Distance Between Borders & 0,04 & 4 & 0,17 & & \\
\hline & B. The Presence of Stairs & 0,33 & & & & \\
\hline $1 \mathrm{~B}$ & Access to Building Exits & 0,77 & 4 & 3,08 & \multirow{4}{*}{3,99} & \multirow{4}{*}{1,30} \\
\hline $2 \mathrm{~B}$ & Distance of Achievement & 0,21 & 4 & 0,83 & & \\
\hline $3 B$ & The Number of Stairs & 0,01 & 3 & 0,04 & & \\
\hline \multirow[t]{2}{*}{$4 B$} & Types of Stairs & 0,01 & 4 & 0,04 & & \\
\hline & C. The Completeness of The Stairs & 0,26 & & & & \\
\hline $1 \mathrm{C}$ & Emergency Lighting & 0,66 & 4 & 2,64 & \multirow{3}{*}{3,66} & \multirow{3}{*}{0,95} \\
\hline $2 \mathrm{C}$ & Signage & 0,32 & 3 & 0,96 & & \\
\hline $3 \mathrm{C}$ & Handrail & 0,02 & 3 & 0,06 & & \\
\hline & & & & & & 3,86 \\
\hline
\end{tabular}




\section{Acknowledgment}

The result of this research is expected to be useful as a reference for the user and the provider of the hospital, to find out the circumstances and problems on the system of fire stairs in building a hospital.

\section{REFERENCES}

[1] Badan Standarisasi Nasional, "Tata Cara Perencanaan Sistem Proteksi Pasif untuk Pencegahan Bahaya Kebakaran pada Bangunan Rumah dan Gedung", Jakarta: Badan Penerbit PU, 2000.

[2] R. Korwa, "Klasifikasi Kebakaran Menurut NFPA," 2016. [Online]. Available: http://rikikorwa.blogspot.co.id/2016/12/klasifikasi-kebakaran-menurutnfpa.html. [Accessed 26 December 2016].

[3] Pemeriksaan Safety, "Persyaratan Teknis Sistem Proteksi Kebakaran pada Bangunan Gedung dan Lingkungan," Pemeriksaan Keselamatan Kebakaran Bangunan Gedung Peraturan Menteri Pekerjaan Umum No. 26/PRT/M/2008, Jakarta, Departemen Pekerjaan Umum, 2005, p. Badan Penerbit Penlitian dan Pengembangan PU.

[4] N. F. P. Association, "Life Safety Code", USA: NFPA 101, 1999. 